\title{
A report of Rhizopus oryzae causing postharvest soft rot of apple fruit in China
}

\author{
Ibatsam Khokhar $^{1,2}$ (D) $\cdot$ Irum Mukhtar ${ }^{3} \cdot$ Junhuan Wang ${ }^{1} \cdot$ Yang Jia $^{1} \cdot$ YanChun Yan $^{1}$
}

Received: 7 November 2018 / Accepted: 5 March 2019/Published online: 15 March 2019

(C) Australasian Plant Pathology Society Inc. 2019

\begin{abstract}
Postharvest soft rot was found on apples in a local market in Beijing, China. Based on the morphological characteristics and molecular analyses of the ITS rDNA regions and Elongation factor alfa-1 ( $E F l-\alpha)$ gene, the causal fungus was identified as Rhizopus oryzae. This is the first report of Rhizopus-associated with soft rot on apple fruit in China.
\end{abstract}

Keywords Rhizopus oryzae soft rot · Apple $\cdot$ Postharvest rot $\cdot$ ITS sequence $\cdot$ Ef- $\alpha 1$ gene

In 2016, China produced 50\% (89.3 million tones) of the world production of apples (Malus pumila). The USA, Poland, Turkey, India and Iran each produce 3$5 \%$ of the world's apples (FAOSTAT 2017). Vegetables, fruits, and ornamental plants are often infected by postharvest pathogens that cause diseases like crown rot, fruit core rot, blue/grey/green mould, anthracnose and soft rot. Fungal infection of fruit and apples can result in significant postharvest losses if it is not stored at suitable environmental conditions or if it is damaged during handling or storage (Agrios 2005). In August 2018, soft rot symptoms suspected of being caused by Rhizopus were detected on apple fruit at local markets in the Haidian district of Beijing, China (39 $57^{\prime} 55.984^{\prime \prime}$ $\left.\mathrm{N}, 116^{\circ} 20^{\prime} 8.124^{\prime} \mathrm{E}\right)$. The earliest symptom on the

Ibatsam Khokhar and Irum Mukhtar contributed equally to this work.

Ibatsam Khokhar

ibatsamk@yahoo.com

Graduate School of Chinese Academy of Agricultural Sciences, Beijing 100081, China

2 Department of Biological Sciences, Forman Christian College (A Chartered University), Ferozpur Road, Lahore 54600, Pakistan

3 Mycological Research Center (MRC), College of Life Sciences, Fujian Agriculture and Forestry University, Fuzhuo 350002, Fujian, China surface of infected fruit were small, water soaked lesions which soon turned brown and rapidly expanded, resulting in a sunken, soft rot of the entire fruit (Fig. 1a). White hyphae developed on the rotten tissue and within three days grey sporangiophores bearing sporangia were produced from the hyphae. The infected fruit were collected from local markets and the fungus associated with the symptoms was isolated on potato dextrose agar (PDA). To isolate the causal agent, small pieces $(2 \mathrm{~mm})$ from rotten lesions were cut from infected fruit samples, sterilised with $75 \%$ ethanol for $20 \mathrm{~s}$ followed by $0.5 \% \mathrm{NaOCl}$ for $3 \mathrm{~min}$, rinsed three times with sterile distilled water, placed on PDA, and incubated at $25{ }^{\circ} \mathrm{C}$ for 2 days.

Purified fungal colonies from infected tissues were initially white and cottony, then became grey to blackishgrey due to mature sporangia on PDA within three days (Fig. 1b). Sporangiophores were mostly erect, unbranched, smooth walled, aseptae, subhyaline to brown, singly or in groups and came up from stolons in opposite direction to rhizoids, in sets of 3-5. Sporangia were globose to subglobose, mostly $35-210 \mu \mathrm{m}$ in diameter, white at first then becoming black due to the production of conidia (Fig. 1e). Columella were mostly globose to sub-globose and 30-90 $\mu \mathrm{m} \times 50-110 \mu \mathrm{m}$. Sporangiospores were abundant, pale greyish to brown, sub-globose or ovoid, angular, having striations, and 3.8- $10 \mu \mathrm{m} \times 3-5 \mu \mathrm{m}$ (Fig. 1f). 

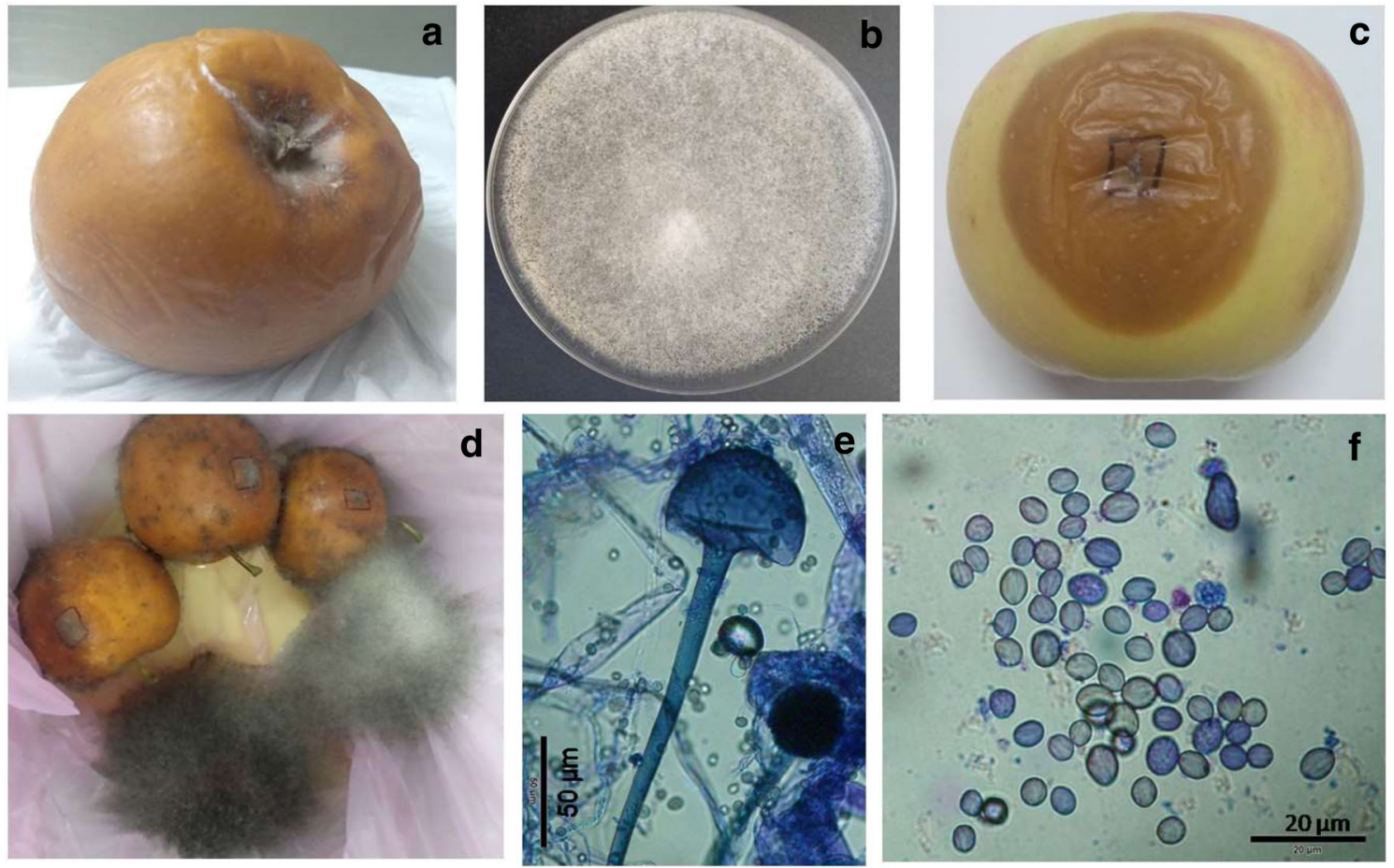

Fig. 1 Rhizopus oryzae on apple - (a) soft rot symptoms on fruit collected from local markets, (b) isolate growing on PDA for 3 days at $25^{\circ} \mathrm{C}$, (c) soft rot symptoms on incubated fruit after 2 days incubation, (d)

soft rot symptoms on incubated fruit after 7 days incubation, (e) sporangiophore bearing a sporangium, (f) sporangiospores

The in vitro growth response to temperature is important to distinguish between Rhizopus stolonifer (syn. $R$. nigricans) which does not grow above $37^{\circ} \mathrm{C}$ and $R$. oryzae which does grows at $40{ }^{\circ} \mathrm{C}$ (Kwon et al. 2014; Schipper and Stalpers 2003). In this study, growth rate was also determined by measuring the diameters of fungal colonies on PDA plates incubated at $40{ }^{\circ} \mathrm{C}$. Rhizopus isolates from affected apples grew at $30 \mathrm{~mm} /$ day on PDA at $40{ }^{\circ} \mathrm{C}$, which together with their morphological features is characteristic of $R$. oryzae. The fungus was identified as Rhizopus oryzae, based on the morphological characteristics and growth temperature (Lunn 1977; Liou et al. 2007; Kwon et al. 2014; Schipper and Stalpers 2003).

Nine cultures of the fungus tentatively identified as $R$. oryzae were grown on PDA at $25 \pm 2{ }^{\circ} \mathrm{C}$ for 4 days for DNA extraction using fungal genomic DNA isolation kit (TIANGEN, China). The internal transcribed spacer (ITS) regions of rDNA and the partial of Elongation factor-alfa1 (Ef- $\alpha 1)$ gene were amplified with primers ITS1/ITS4 (White et al. 1990) and EF1-728F/EF1-986R (Carbon and Kohn 1999) respectively, and sequenced.
DNA sequences of the nine isolates were identical, therefore, ITS (MH973158) and Ef- $\alpha 1$ (MK310275) sequences of a representative isolate (YC-IK4) were deposited in Genbank. The resulting ITS and Ef- $\alpha 1$ sequences showed 99\% similarity with $R$. oryzae accessions (HQ897687, MH156644, MF470368, AB097334, AB181304, $\mathrm{AB} 281527, \mathrm{AB} 281530$, AB281531, AB281534, $\mathrm{AB} 281540$ ). The fungal isolate YC-IK4 is deposited (CGMCC Accession No.16961) in the China General Microbiological Culture Collection Center, Bejing, China (Fig. 2).

To prove Koch's postulates, nine apples were artificially inoculated with isolate YC-IK4 using a wound infection method. A spores suspension $\left(0.1 \mathrm{~mL} ; 10^{6}\right.$ conidia/ $\mathrm{mL}$ of sterile distilled water) was injected under the surface of each apple at one point using a sterile needle under aseptic conditions in a laminar flow cabinet. Three apples were inoculated with sterile distilled water as a control treatment. All inoculated apples were placed in a closed chamber at $80 \% \mathrm{RH}$ and $30{ }^{\circ} \mathrm{C}$. After $48 \mathrm{~h}$ of incubation, fungal rot symptoms, similar to those on affected fruit collected from the local markets, developed on 


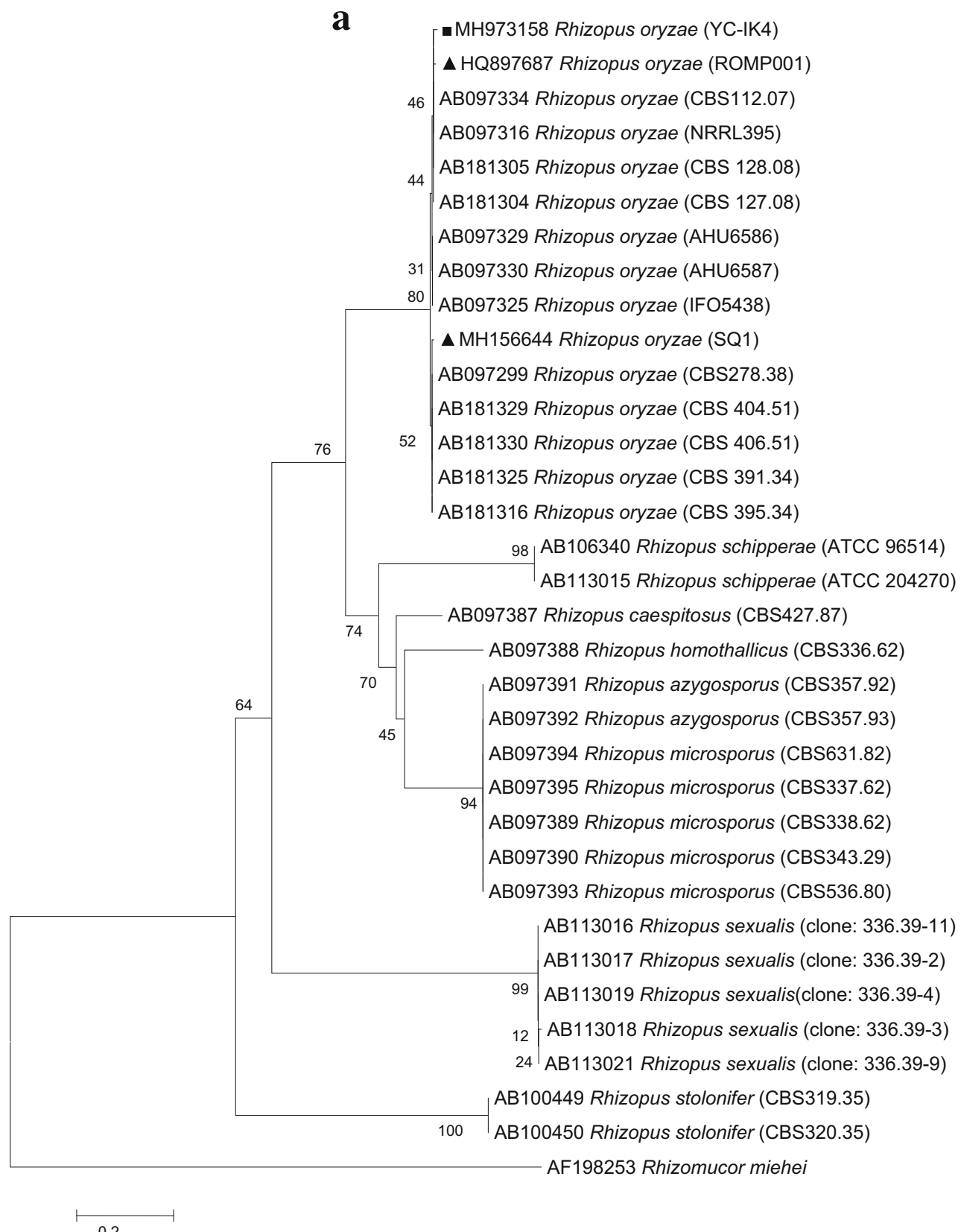

Fig. 2 Neighbor-Joining (NJ) phylogenetic trees of genus Rhizopus, Based on (a) the rDNA ITS sequence and (b) Elongation factor- $\alpha 1$ (EF- $\alpha 1)$ gene. $\mathrm{MH} 973158$ Rhizopus oryzae (YC-IK4) is isolated from

the inoculated apples. Control apples remained asymptomatic. The causal fungus was reisolated from the artificially infected apples and was identified as $R$. oryzae.

Postharvest soft rot of apple, sweet potato, and banana fruit caused by $R$. oryzae (syn; R. arrhizus) have been apple from china while $R$. oryzae sequences $\boldsymbol{\Delta}$ HQ897687 (ROMP001) and $\boldsymbol{\Delta}$ MH156644 (SQ1) indicate isolates reported on apple from Korea and Saudi Arabia respectively

reported in Korea and Saudi Arabia (Kwon et al. 2011, 2012a, b; Al-Dhabaan 2018). The pathogen has also been reported to be associated with postharvest root rot of Codonopsis lanceolata in Korea (Park et al. 2014). However, to our knowledge, this is a new record of 


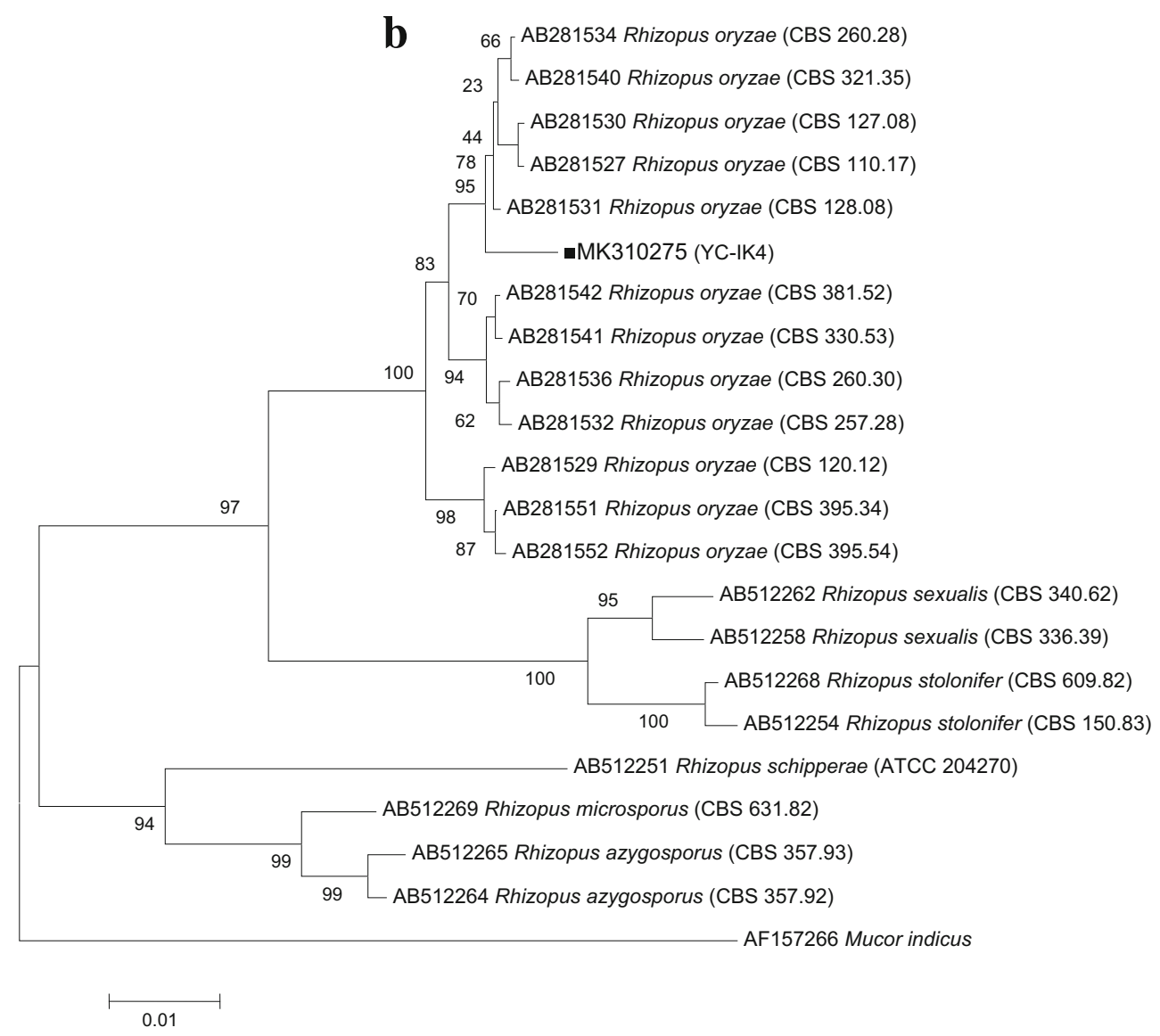

Fig. 2 continued

$R$. oryzae as a postharvest pathogen causing soft rot on apple in China.

\section{References}

Agrios GN (2005) Plant pathology, 5th edn. Academic Press, New York Al-Dhabaan FA (2018) First record of Rhizopus oryzae from stored apple fruits in Saudi Arabia. Plant Pathol Quar 8:116-121

Carbon I, Kohn LM (1999) A method for designing primer sets for speciation studies in filamentous ascomycetes. Mycologia 91:553-556

Food \& Agriculture Organization, Statistics Division. 2017. "Apple production in 2016; crops/world regions/production quantity". FAOSTAT, UN Retrieved 28 May 2018

Kwon JH, Kim J, Kim WI (2011) First report of Rhizopus oryzae as a postharvest pathogen of apple in Korea. Mycobiology 39:140-142

Kwon JH, Kim MK, Choi O, Kim J (2012a) First report of Rhizopus oryzae as a postharvest pathogen of sweet potato in Korea. Plant Pathol J 28:114

Kwon JH, Ryu JS, Chi TTP, Shen SS, Choi O (2012b) Soft rot of Rhizopus oryzae as a postharvest pathogen of banana fruit in Korea. Mycobiology 40:214-216
Kwon JH, Kang DW, Yoon HS, Kwak YS, Kim J (2014) Rhizopus fruit rot caused by Rhizopus oryzae on strawberry. J Agri Life Sci 48:2734

Liou GY, Chen SR, Wei YH, Lee FL, Fu HM, Yuan GF, Stalpers JA (2007) Polyphasic approach to the taxonomy of the Rhizopus stolonifer group. Mycol Res 111:196-203

Lunn JA (1977) Rhizopus oryzae. CMI descriptions of pathogenic fungi and bacteria. No. 525. Kew: Commonwealth Mycological Institute; Ferry Lane, Kew, Surrey, England

Park JH, Cho SE, Kim BS, Shin HD (2014) First report of postharvest root rot caused by Rhizopus oryzae on Codonopsis lanceolata. Aust Plant Dis Note 9:135

Schipper MAA, Stalpers JA (2003) Zygomycetes: The order Mucorales. In: Howard DH (ed) Pathogenic fungi in humans and animals. Marcel Dekker Inc., New York, pp 67-125

White TJ, Bruns T, Lee S, Taylor JW (1990) Amplification and direct sequencing of fungal ribosomal RNA genes for phylogenetics. In: Innis MA, Gelfand DH, Sninsky JJ, White TJ (eds) PCR protocols: a guide to methods and applications. Academic, San Diego, pp 315322 